\author{
Јелица Р. СТОЈАНОВИЋ ${ }^{*}$ \\ Универзитет Црне Горе \\ Филолошки факултет, Никшић
}

Оригинални научни рад

Примљен: 03. 12. 2018.

Прихваћен: 14. 02. 2019.

\title{
АНТРОПОНИМИЈСКИ СИСТЕМ И АНТРОПОНИМИЈСКЕ КАТЕГОРИЈЕ У ПАШТРОВСКИМ ИСПРАВАМА (16-19. ВИЈЕКА)
}

\begin{abstract}
Циљ нашег рада је да представимо антропонимијски систем Паштровских исправа 16/17. вијека и ставимо га у контекст шире српске антропонимије. Као што је специфичан језик Паштровских исправа, тако се значајним и особеним показује и антропонимија. Исправе су свједочанство преласка патронима на -uћ у презимена; преовладавају двосложна мушка имена на -о, као и женска двосложна имена на -е; хришћанска имена (и имена образована од ових основа) у знатној мјери преовладавају над словенским именима. Женска имена су ријетка, како због тога што се Паштровске исправе односе на судска и правна акта, тестаменте, те су у њима мање учествовале жене, тако и због тога што се жена најчешће именује по оцу, мужу, брату.

Кључне ријечи: антропонимијски систем, антропонимијска категорија, лично име, патроним, презиме, суфикс, хришћанска имена, словенска имена, Паштровске исправе.
\end{abstract}

1. Паштровске исправе садрже изузетно занимљив материјал за језичка, филолошка и културолошка проучавања, представљају изузетно драгоцјен извор за проучавање и антропонимијског система једног микроареала у дијахроној перспективи. Наиме, исправе посједују можда најзначајнију грађу у српском језичком насљеђу у периоду 16-17/18. вијека јер је из овог периода најмање сачуваних споменика писаних српским народним језиком. Настале су на подручју које је било доста одвојено од околних простора, историјски под управом или утицајем различитих држава: Млетачке републике (најдуже, од 1423. до 1797. године), Аустрије, Француске, Русије. Уговором су се Паштровићи приклонили Млетачкој републици пред турском најездом 1423. године, а Ластва (данашњи Петровац) 1442, чиме је простор између Будве и Бара уживао политичку аутномију са великим степеном самосталности. Као 
производ тога сачуван је велики број пословно-правних докумената, писаних српским народним језиком. Како је простор Паштровића био доста изолован, то се задржао и развио велики број особених и у великој мјери архаичних и аутохтоних језичких црта, које су од посебног и ријетког значаја и за српску историјску дијалектологију.

Највише докумената писано је и чувано у познатим паштровским манастирима (Градиште, Прасквица, Режевићи и Дуљево), али је доста тога сачувано и у породичним збиркама. Најбогатија збирка докумената чува се у манастиру Прасквица, према нашој евиденцији исправа 16-19. вијека је око 700. Извршили смо фотографисање ове збирке из манастира Прасквица, из Државног архива на Цетињу и Државног архива у Будви: из 16. вијека 58 исправа, а из 17. - 160, из 18. вијека 230, а из 19. - 150, дакле 582 исправе 16-19. вијека, што представља репрезентативан корпус за сагледавање дате проблематике. За ову прилику успјели смо да обрадимо корпус 16/17. вијека.

У оквиру антропонимијских категорија посматраћемо формално-граматички тип именовања лица (творбену структуру) и семантички аспект (ономатолошко значење). Антропонимски систем Паштровића је драгоцјен, са многим посебним цртама, свједочанство је једне карике у историјском и ареалном континуитету српског језика .

Шта нам се као опште мјесто намеће у антропонимијском систему Паштровића (судећи према нашем корпусу): 1) Уз лично име иде обавезно патроним; 2) Патроним је изведен прије свега суфиксом -ов (Ников) (уз могуће -(ов)uћ: Новаковић), или изражен генитивом уколико се додаје патроним (на -ов) и(ли) презиме (Нико Мара Стијепова / Никола Мара Греговића); 2а) Постоји и тип име + презиме (или патроним, остаје отворено питање) на -(oв)uћ; 3) Нијесу ријетка презимена на -(ов)uћ, а да су то (највјероватније) презимена (настала од не тако давних патронима), показатељ је то што се јавља лично име + патроним + презиме, а потом се антропонимијска одредница на -(ов)uћ преноси код даљих потомака; 4) Презимена нијесу ријетка. Паштровиће, с обзиром да нијесу били под турском управом, одликује чување и преношење презимена од раног периода кроз вјекове; 5) Чести су случајеви низања, нарочито у 18. вијеку: име по оцу + име по дједи + име по прадједи... (нпр. Мило Никиа Ивова Калуђеровић, П.Џ./1684), при чему се име предака веома често понављало, нпр. Нико Мара Ника Марова/Стијепова Греговића); 6) Женска имена су ријетка, често се као одредница за лице женског пола наводи: „жена тог и тог мужа” (нпр. жена Мара Рајина), „ћерка тог и тог оца” (нпр. кћи Николе Маркова), „сестра тог и тог брата”. Жена се најчешће именује уколико је муж/отац покојни (Анђе кћи покојнога Мара Перова); 7) Најфреквентнија су мушка двосложна имена на -о (Нико, Радо, Маро, Вуко...): од укупно забиљежених именовања различитих лица (око 700), половина су на -о, те женска двосложна на -е (Маре, Јоке, Стане...); 8) Хришћанска (црквена) имена (и она изведена од ових основа) представљају неупоредиву већину у односу на словенска имена.

2. Уз лично име у Паштровићима, судећи према Паштровским исправамa, иде, као обавезно, и патроним, изведен прије свега суфиксом -ов (Ников) 
(рјеђе -[ов]uћ: Новаковић), или изражен генитивом, уколико се додаје презиме или други патроним, типа: Нико Вујаков (1588), Нико Андрин (1588), Нико Гојка Хенуре (1591), Нико Рада Николина (Грег.,пр.зб./1592.2), Нико Никиа Никова (П/1595, бр. 6), Нико Милојевић (ДАЦ.Дав./1599), Нико Буљаревић (Грег., пр.зб./1603), Нико Никмиловић (П/1608), Нико Марков Греговић (ДАЦ. Дав./1631), Нико Франов (П. пр.зб./1638.2), Нико Франаљев (П. пр.зб./1639), Радо Алексе Бранковића, Радо Вуксанов Арменковић, Андрија Никиа Голиша (ДАЦ. Грег./1672, бр.18).

Овај однос намеће једно питање: однос суфикса на -(ов)ић и -ов, а посебно занимљиво питање јесте када је суфикс -(ов)ић патроним, када презиме, односно када је од патронима почео да носи значење презимена, откад је од значења „син свог оца” добио значење „потомак дједа/предака”. Антропонимијски систем Паштровских исправа умногоме је показатељ почетног стадијума, те може послужити као свједочанство како долази до формирања презимена. Према Радмилу Маројевићу, мушки патроними су се изводили од основе посесивног придјева од личног имена помоћу именичког суфикса - $и \hbar$ (у словенском насљеђу, српском, одн. српскохрватском), имали су у свом саставу посесивну придевску морфему (Владислав- - Владислављ - Владислављић) ${ }^{1}$, чиме се лице именује посредно, преко очевог имена (Маројевић 1984:184), за разлику од прасловенског непосредног именовања (лично име): Владислав ${ }^{2}$, „Мушки патроними на -ић су жива категорија све до првих деценија XV века. На бази патронима на -ић формиран је основни тип српских презимена. Облици типа Петровић, Петровићи, поред значења 'Петров син, Петрови синови', добијају значење 'Петров потомак, Петрови потомци', да би ово секундарно значење постало најпре основно, а затим једино. Тако су током XV века формирана српска презимена на -ић” (Маројевић 1984: 186).

Према Маројевићу, антропоними на -ић почели да значе презимена кроз 15. вијек: „Неки средњовековни споменици показују да су се патроними на -ић преносили на следећу генерацију, што је сведочанство да су добили друго значење 'Владимиров син', добио значење 'Владимиров унук (потомак)', а патронимско значење облика на -ић потискује се, замењујући се генитивном синтагмом (односно инфиксом -ов)" (исто).

Суфиксу -ов (у значењу патронима) додаје се (или парира) суфикс -uћ (такође некадашњи патроним) тако да се добија нови патроним (-[oв]uћ), који паралелно почесто има и значење патронима („,син свог оца”) и значње презимена (,унук/потомак свог претка”).

\footnotetext{
${ }^{1}$ „Српски феудалац друге половине XIV века Војислав Војиновић именује се тако зато што се његов отац звао Војин. Син Војислављевог брата Алтмана звао се Никола Алтмановић. Према томе, антропоними Војиновић и Алтмановић су патроними са значењем 'Војинов син', 'Алтманов син', а не презимена. Син кнеза Лазара је Стефан Лазаревић. Антропоним Мрњавчевић, Вукашина и Угљеше Мрњавчевића такође није презиме, него име по оцу 'Мрњавчев син', изведено од личног имена (надимка) Мрњавац...” (Маројевић 1984: 186).

${ }^{2}$ „Прасловенски језик је имао, прво, лична имена, мушка и женска. Са формалне старне ова антропонимска категорија се одликовала одсуством посесивне придевске морфеме (суфикса) у свом саставу. Са семантичке стране лична имена карактерише непосредна номинација: лице се личним или 'рођеним' именом именује непосредно, а не преко имена другог лица” (Маројевић 1984: 183).
} 
Шта нам показују Паштровске исправе у вези са овим: 1) Обавезна је употреба патронима: са инфиксом -ов (-ин), уколико иде само име (+ патроним), тип: Нико Марков; потом, веома се често употребљавају патроними у Гј. При томе разликујемо тип: л. име + патроним у Гј + други патроним на -ов (или презиме на -ић) (Нико Марка Вукова/Вуковића). У случајевима на -(ов)uћ поставља се питање да ли облици на -ић представљју презимена или патрониме: да ли је то: лично име + патроним + патроним или лично име + патроним + презиме. Конкретни примјери нам показују да то може бити и једно и друго, односно да је процес у превирању, истовремено носи оба значења да би у конкуренцији преовладало презиме. О томе нам говоре конкретни примјери из Исправа: напоредо се употребљавају облици на -ов и на -(ов)uћ, чак и у истом документу, а односе се на иста лица: Вуко Новаков/Вуко Новаковић (П/1598, бр. 114), Вуко Радаковић/Вуко Радаков, Стјепо Јунков/Стјепо Јунковић (П/1610 и 1619), Давид Вукашиновић/Давид Вукашинов (П/1598), Нико Никандровић/Нико Никандров (П/1612, бр.328), Андрија Дабовић/Андрија Дабов (1529, бр. 1), Никола Буљаревић/Буљар (ДАЦ. Дав./1604), Иван Голубовић/Иван Голубов (П.Џ./1588,1), Вуко Радаковић/Вуко Радаков (Грег.,пр.зб./1591). Облици на -ов почињу да преовладавају као патроними, потискујући облике на - $ћ$, а облици на -(ов)ић добијају значење презимена. Дакле, како грађа показује, једно вријеме су и суфикси на -ов и суфикси на -(ов)uћ имали значења патронима („син свог оца”) да би потом -ов остајало у значењу патронима, -(oв)uћ се употребљавало у значењу и патронима и презимена, да би се потом уопштило у значењу потомка (било ког) и почињало да добија значење презимена.

У примјерима типа: Нико Милојевић (ДАЦ.Дав./1599), Нико Буљаревић (12. Грег., пр.зб./1603), Нико Никмиловић (П/1608), такође остаје отворено питање да ли су облици на -(ов)uћ патроними или презимена, а на њега се може одговорити само у ширем контексту (уколико је могуће утврдити да ли се уопштило на више генерације). Нико Никмиловић (П/1608), може бити и патроним и презиме, али већ примјери типа Андрија Ника Никмиловића (П/1611), тј. примјери који садрже лично име + патроним (на -ов или Гј.) + облик на -(ов)uћ говоре у правцу формирања презимена на -(ов) $u \hbar$. Таквих примјера има доста у Паштровским исправама: Нико Марков Греговић (ДАЦ. Дав./1631), Радо Алексе Бранковића, Радо Алексе Дмитровића (П/1594, бр. 9), Радо Вуксанов Арменковић (ДАЦ. Грег./1672, бр. 18), Иван Андрије Давидовића (ДАЦ. Дав./1604), Нико Пјера Харвојевића, Андрија Никчева Cmјепковић (П. пр.зб./1677).

3. У Паштровићима (судећи према Паштровским исправама), имена су се понављала кроз покољења (нпр. Нико Никиа Никова, П/1595, бр. 6; Франо син Рака Франова, П/1680, бр. 193), а у оптицају је био не тако велики број имена. Забиљежено је око 110 различитих имена којима је именовано око 700 лица. Међутим, фреквенција неких имена је велика тако да је помоћу 11 имена (5 двосложних на -о: Нико, Вуко, Стијепо/Стјепо, Радо, Франо, 6 хришћанских: Никола, Стјепан, Лука, Андрија, Иван, Петар) именовано близу 600 лица, док су остала имена мале фреквенције. 
3.1. Двосложна имена на -о (данас у нормативном српском језику са дугоузлазним акцентом на првом слогу, а у говору Паштровића са дугосилазним на првом слогу, ${ }^{3}$ чему је претходило стање са дужином на првом са краткосилазним акцентом на ултими, данас задржано у многим говорима) преовлађују у Паштровским исправама, што можемо сматрати њиховом изразитом специфичношћу. Њима је именована половина лица: Нико - 117, Стијепо/Cтјепо - 56, Вуко - 46, Радо - 35, Маро - 26, Франо - 22. Осталим именима овог типа (рјеђе фреквенције): Ђуро, Јово, Боко, Дабо, Дако, Перо, Мрко, Андро, Перо/Пјеро, Вучьо, Вучо, Видо, Иво, Медо, Зано, Боћо, Шуро, Мило, Анто именовано је 61 лице (дакле, заједно: 353). Осим ових, специфичност овог подручја су и имена изведена суфиксом -ко (Вулко, Дабојко, Гојко, Живко, Динко, Марко, Бошко, Јанко, Јунко, Франко, Домко, Трипко, Станко), којима су именована 52 лица. Забиљежена су и тросложна имена која формално на крају имају -о (Лесандро, Гаврило, Маркето), као и двосложно име Крсто, којима је именовано десетак лица. Сва ова имена се формално завршавају на -о. Дакле укупно је њима именовано 420 лица наспрам 400 свих осталих (што значи више од половине). Наводимо дио корпуса: НИКО (117). Нико Гојка Хенуре (1591), Нико Никиа Никова (П/1595, бр. 6), Нико Белин (П/1598, бр. 67), Нико Хекура Канош (Грег.,пр.зб./1598), Нико Николић (ДАЦ.Дав./1599, 1. децембар), Нико Луке Прековића (ДАЦ. Грег./1611, бр. 12), Нико Вука Томина (П/1612, бр. 328 (228)), Нико Никандровић (П/1612, бр. 328), Нико Никандров (46.П/1612, бр. 40), Нико Рада Дмитровића (П.Џ./1627), Нико Андрије Стијеповића (П.Џ./1627), Нико Марков Греговић (ДАБ.Суђ./1638, бр. 1-2.a1), Нико Лукшин Дабовић (195. П/1651.2);

РАДО (35). Радо Лучин (Грег,пр.зб./1590), Радо Алексе Бранковића (П/1591, бр. 48), Радо Алексе Вукмировића (Грег.,пр.зб./1593), Радо Никаљев (П/1604, бр. 109), Радо Вука Налетића (Грег.,пр.зб./1612), Радо Арменков (П. пр.зб./1614);

ВУКО (46). Вуко Дајков (П/158(1) (бб)), Вуко Новаков, Вуко Новаковић (П/1598, бр. 114), Вуко, син Ника Ивкова (П/1611, бр. 71), Вуко Радаковић, Вуко Радаков (П/око1631, бр. 17), Вуко Брнковић (ДАБ. Суђ./1676, бр. 1);

МАРО (26). Маро Ников (П/1619, бр. 329), Маро Никошић (П.пр. зб./1624), Маро Стјепияа Рајина, Маро Стијепов (П.пр.зб./1632.2), Маро Стијепа Карлова (П. пр.зб./1646), Маро Братићев (П.Џ./1678);

СТИЈЕПО/СТЈЕПО (56). Стијепо Николин (Грег.,пр.зб./1591), Стијепо Раичевић (П/1608, бр. 53), Стијепо Ивана Никошића (П. пр.зб./1610), Стијепо Љубиша (Грег.,пр.зб./1612;1), Стијепо Јована Раичкова (П. пр.зб./1632), Стијепо Лучище Франкова (П.прив.зб./1634), Стијепо Марка Каикова (П/1634, бр. 119), Стијепо Луке Карстићева (П/1637, бр. 42);

ФРАНО (22). Франо Бушатов (Грег.,пр.зб./1598), Франко Алексин (П/1603, бр. 264), Франо Никияа Франкова (П/поч.17.в.), Франо Цановић (П.Џ./1673.В), Франо, син Рака Франова (П/1680, бр. 193);

Остала имена на -о су мање фреквенције (забиљежена су 61 пут).

${ }^{3}$ УП. Јовановић 2005: 282-283. 
ЂУРО. Ђуро Дабижив (П/1594, бр. 4), Ђуро Вучинов (Грег.,пр.3б./1598), Ђуро Главина (ДАЦ.Дав./1599); ЈОВО. Јово Љубиша (П. пр.зб./1614.3), Јово Ника Вукшина (П.пр.зб./1646), Јово Сћепчев; БОКО. Боко Николин (ДАЦ.Грег./1599, бр. 7); ДАБО. Дабо Никовић (П/17.в., бр. 164), Дабо Николин (П.Див./1603), Дабо Хрвојевић (П.Див./1651); ДАКО. Дако Путник (П. пр.зб./1626); ПЕРО. Перо Занов (ДАБ. Маин./1606), Пјеро Франа Петрова (П/1620); МРКО. Мрко Лукетин (П. пр.зб./1614.3), Мрко Динковић (П/1673); ВУЦО, ВУЧО, ВУКО, ВИДО. Вуизо Франков (П. пр.зб./1621, бр. 17), Видо Куљача (П/1622, бр. 30), Вучо Петров (П/1622, б.б.), Вуцчо Ников (П/1628), Вук(о) Николин, Вуц̧о Петров, Вуко Николин (Грег.,пр.зб./1676); ИВО, МЕДО, ЗАНО, БОЋО, БОКО, АНДРО/ЈАНДРО, ШУРО, АНТО, МИЛО, КРСТО. Боко Николин (ДАЦ.Грег./1599, бр. 7), Андро Дабов (П. пр.зб./1619), Иво Дрекша (П/око1631, бр. 17), Шуро Транут Крастић (П/1634, бр. 64), Андро Јованов (ДАЦ.Грег./1639, бр. 16), Андро Сћепчев (П/1679, бр. 227), Анто Батута, Мило Никиа Ивова Калуђеровић (П.Џ./1684), Јандро канзалијев (П/1633, бр. 52), Боћо Попов (Грег.,пр.зб./1674), Зано Краљевић (П/1589, бр.175), Карсто Трипковић (П/1640.2).

2.2. Забиљежено је и 16 различитих имена са суфиксом -ко, којима су именовна 52 лица: ВУЛКО, ДАБОЈКО, ГОЈКО, ЖИВКО, ДИНКО, МАРКО, БОШКО, ЈАНКО, ЈУНКО, ФРАНКО, ДОМКО, ТРИПКО, СТАНКО: Вулко Николин, (Да)бојко Николин, Гојко Хенура (П/1599, бр. 48). Бојко Николин (П/1594, бр. 105), Јанко Николин (П/1598, бр. 67), Маркето Андричин (Грег.,пр.зб./1598), Јунко Голубов (П/1598, бр. 40), Франко Алексин (П/1603, бр. 264), Домко Раићков (П.Див./1603), Марко Андрије Давидовића (Грег., пр.зб./1603), Динко Марчић (П/1637, бр. 128), Живко Териза (П/1672), Станко Калуђеровић (П.Џ./1688).

2.3. Јављају се и вишесложна имена (различитог постања) која на крају (формално) имају -о. Забиљежили смо три тросложна: МАРКЕТО, ЛЕСАНДРО, ГАВРИЛО (којима је именовано 12 лица): Маркето Раића Николића (ДАЦ.Грег./1591, бр. 1), Лесандро Жинтилииа (П/1627, бр. 115), Гаврило калућер (П/1627, бр. 225), Лесандро Калођурђевић (П/1681).

Дакле, у Паштровским исправама, а судећи према њима и у Паштровићима, као особеност, јављају се лична имена која на крају имају -о (што је најчешће суфикс, мада не једино).

3. Што се тиче односа хришћанских имена (неизведених и изведених од хришћанских основа српским суфиксима) и словенских, знатну превагу имају хришћанска имена (којима је именовано око 600 лица), над словенским (именовано око 170 лица). Међу најфреквентнијим хришћанским су: Лука (Лучииа, Лукша, Лукета) - 76; Стјепан/Сћепан - 70; Анрдија (Андро) - 51; Никола (Никаљ) - 42; Иван (Иванко) - 33; Петар - 18; остали (Давид, Томо, Дамјан, Илија, Сандаљ, Марин/Марко/Марчић, Франић, Лесандро) - 28.

Овом особином се Паштровићи у великој мјери не уклапају у опште тенденције историјске антропонимије српског језика у којој преовладавају имена са словенским општим дјеловима. Тако у 14. вијеку, судећи према повељи Стефана Дечанског, знатно преовладавају словенска имена: „У повељи 
Стефана Дечанског, записаној на зиду манастира Жиче, забележено је 217 имена. Од тога је 168 словенског порекла, 11 из хришћанског календара, а 38 супстратског или непознатог порекла. Ако се овај извор узме као случајан узорак, онда је 77\% словенских имена у њему значајан показатељ, не само за антропонимијску слику него и за словенску доминацију у земљи Стефана Првовенчаног. Слично стање је и у време краља Милутина. У Светостефанској хрисовуљи, насталој између 1313. и 1318. године. Од 547 имена, 476 је словенског порекла, 21 из хришћанског календара, а свега 50 супстратског или непознатог порекла... Из досадашње анализе је проистекао закључак да се Срби у првој половини четрнаестог века веома добро чували основне карактеристике општесловенског антропонимијског наслеђа" (Грковић 1983: 13, 36). Иако се временом број хришћанским имена повећава у српском ономастикону, словенска имена заузимају значајно мјесто кроз све вјекове за разлику од неких других подручја гдје је, под различитим утицајима, сузбијана употреба имена словенског поријекла: „U novu su postojbinu naši preci prenijeli i svoja osobna imena. Bijahu to općeslavenska (praslavenska imena). Odavno se ona s pravom nazivaju hrvatska odnosno srpska, kao što su ista baštinjena imena postala bjeloruska, bugarska, češka, kašupska, lužička, makedonska, ruska, slovačka, slovenska, ukrajinska. Mnoga su izniknula na ovome tlu u tijeku kasnijih stoljeća, stvaraju se također i danas. I življe negoli u ijednome dosadašnjem razdoblju" (Шимундић 1988: X).

За опстанак словенских имена код Срба несумњив допринос имала је и српска црква, односно њена отвореност и ширина: „Српска црква никада није заузимала неки званичан став када је реч о именима; била је из неког разлога веома толерантна према старом словенском именослову, што ће на српским земљама омогућити дуг и несметан живот словенских имена све до данашњег дана" (Јовановић 2006: 34). Потврду за то налазимо и у предању: „Први српски архиепископ Сава (1174-1235) поверио је свештенству да насилно и узалудно не прогоне стара народна веровања и обичаје, него да им даду хришћанско обележје” (Чајкановић 1994: 171).

Већ од 15. вијека знатно се шири број црквених имена, а почев од 15. вијека почиње да се шири творба од ових имена изведених словенским творбеним моделима што значи да су се имена већ одомаћила. Поредећи два временски блиска споменика (Скадарски земљишник из 1416. године и турски тефтер за Скадарски санџак из 1485. године), Пешикан закључује: „смањен је удео имена од словенских основа а увећан удео хришћанских имена, с тим што се јављају само у изведеницама Ђурађ (Ђура, Ђуриц, Ђуро) и Никола (Ника, Никац, Кола, Колац)" (Пешикан 1986: 100).

Како налазимо и код Гордане Јовановић, „деривација хришћанских имена начелно касни за словенском, а у њој можемо пратити два процеса: с једне стране развој саме суфиксације, а с друге процес стварање модификованих основа, погодних за деривацију, тј. аналогних словенским основама" (Јовановић 1994: 175). У Паштровским исправама честа су извођења хришћанских имена српским суфиксима, а има и имена која су забиљежена само као изведена (Лесандро, нпр.). Двосложна на -о су далеко фреквентнија него 
неизведена црквена имена, односе неупоредиву превагу над свим осталим (Нико - 117, Стијепо/Cmјепо - 56, Маро - 26, Франо - 22), што значи да су се сасвим одомаћила. Наводимо дио корпуса, са намјером да одсликамо антропонимију Паштровских исправа.

Име НИКОЛА, и изведенице НИКАљ, НИКАЦ, спадају међу најфреквентнија (изведено Никаи је знатно чешће него Никола, уз најфреквентније Нико са 117 потврда, што је далеко најдоминантније, а што је представљено претходно). Њима су именована 42 лица: Никаљ Алесин (П/1529), Никола Турјагов (ДАЦ.Грег./1591, бр. 1), Никола Вука Алексина (П/1594), Никола Буљаревић/Буљьар (ДАЦ.Дав./1604), Никач Лучице Вукова (П/1629, бр. 75), Никаи Маркета Сћепчева (П прив.зб./1634), Никаи Стјепца Вуксанова (ДАЦ. Дав./1639), Нико Лушин (ДАБ.Суђ./1656, бр.1-3.а.2), Никаи Стјепича Лучичина (ДАЦ. Грег./1677);

Именом СТЕФАН (оДНосно СТЈЕПАН/СТЕПАН / СЋЕПАН / СЕПЧА / СТЈЕПАЦ) именовано је 70 лица (поред претходно представљеног Cmujeno/ Cтјепо којим је именовано 56 лица): Степан Бранковић, Степан Ћуновић (ДАЦ.Дав./1567, бр. 1.), Сепча Бранковић (П/1584, бр. 91), Степан Никандровић (ДАЦ.Дав./1590, бр. 4), Стјепан Јунковић (Грег.,пр.зб./1601), Стјепаи Вуксанов (ДАЦ.Грег./1601, бр.10), Стјепац Бућен (П/1606, бр.14), Стијепо Ивана Никошића (П. пр.зб./1610, 8. Новембра), Стјепо Јунков, Стјепо Јунковић (30. П/1610 и 1619, бр. 184), Сћепан Крековић, Стјепан Рахољевић (П/1611, бр. 71), Степаи Кнежевић (П/1626, бр. 22), Стефан Давидовић, Стефан Бечић (П/1629), Стјепаи Вука Бошкова (П. пр.зб./1646), Стјепаи Мара Каиков (П/1649, бр. 25);

Име ЛУКА (са изведеницама ЛУЧИЦА / ЛУКША / ЛУША / ЛУКЕТА) забиљежили смо у 76 именовања: Лука Ђуда (1529, бр. 1), Лука Сандаља Богојева (П/1595, бр. 122), Лучица Милојевић, Лучица Ников (П/1598, бр. 67), Лучица Рада Дамјанова (Грег.,пр.зб./1598), Лукиа Шаптин (П/1611, бр. 71), Лукета Маринов (П/1612, бр. 328), Лукета Лучин (П.Див./1613), Луша Новачићев (П. пр.зб./1614), Лухиа Маров (П/1620), Лукша Иванов (П/1624, бр. 170), Луша Петров (П/1672); а АНДРИЈА/ЈАНДРИЈА (АНДРО / АНДРИЦА) 51: Андрија Дабовић (1529, бр. 1), Андрија Дабов (П/1529), Андрииа Турковић (ДАЦ.Дав./1590, бр. 4), Андро Ћурин (П/1596), Јандрија Нииић (П/1621, бр. 68), Јандрија Радов (П/1628), Андрија Рада Дабчева (П.Џ./1648), Андро Лукиин, Андро Никчев (П/1651);

Име ИВАН (и ИВАНАЦ/ИВАНИЦ) забиљежили смо 33 пута: Иван Луке Жинтилица (П/1582, бр. 40), Иван Милиновић, Иван Голубовић/Иван Голубов (П.Џ./1588,1), Иванаи Николин (П/1617, бр. 63), Иван Никиа Ивова (П.Џ./1688.2), а ПЕТАР (ПЕТРИЦА) - 18 (уз фреквентније ПЕРО): Петар Харвојевић (П/1585, бр. 120), поп Петрица (П. пр.зб./1614.2), Петар Лукетин (П. пр.зб./1626), Петар Томин (П.Џ./1678.1), Петар Франов (П.Џ./1684).

Остала хришћанска имена су појединачна: ДАВИД (именовано 6 лица), ТОМА/ТОМО (5), ФИЛИП (4), МАРТИН, ДАМЈАН, АЛЕКСА, ИЛИЈА, САНДАЉ, ХЕРАК: Давид Вукашиновић/ Давид Вукашинов (П/1598), Давид Сћепшев Давидовић (Грег.,пр.зб./1693), Тома Буљар Томић (ДАЦ.Грег./1601, 
бр. 10), Алекса Никовић (П/ 1529), Дамјан Радманов (П/1594), Илија Андров (П/1596), Дамјан Ђурђевић (ДАЦ.Грег./1599, бр. 6), Сандаљ Плеша (П/1617, бр. 63), калужер (П/1634, бр. 94), Мартин Никадровић (П/1641, бр.124), Херак Андричин (П/1598, бр. 40).

Лично име МАРКО забиљежено је ријетко у основном облику, чешће у изведеним формама, прије свега Маро - 26, потом: МАРИН, МАРКЕТО, МАРИЈАН, МАРЧИЋ: Марин Николин (ДАЦ.Дав./1590, бр. 4), Марко Донковић (П/1596, 5.априла), Маријан Медовић (П/1611, бр. 39), Мачић Лучин (ДАЦ. Дав./1639), Маркето Степев Греговић (ДАЦ. Грег./1655, бр. 17), Марчић Кукавииза (П. пр.зб./165.).

Осим фреквентног ФРАНО, срета се и име ФРАНИЋ (њиме су именована 3 лица): Франић Радов (П/1631, бр. 34), Франић Никчев Нобиле (П.Џ./1685).

Како из представљеног корпуса можемо видјети, број хришћанских имена (и изведених од хришћанских основа) није велики, али је њихова фреквенција знатна. Понављана су, најчешће, иста имена. То што је најфреквентније име Никола (иначе често у српском именослову), и имена изведена од овог основног имена, за подручје Паштровића могло је утицати и то што је Свети Никола заштитник путника и помораца, а Паштровићи су били упућени на море и путовања.

4. Словенска лична имена нијесу многобројна. Уз двосложна ВУКО (46), РАДО (35), која су далеко најфреквентнија, забиљежено је још 65 различитих именовања различитих лица, а број различитих имена није велики. Углавном су изведене од основе ВУК- (20 различитих имена од основе вук- којима је, изван имена ВУКО, именовано око 50 лица: ВУКАШИН, ВУЛЕТА, ВУЧИНА, ВУКОСЛАВ, ВУЛИЈА, ${ }^{4}$ ВУК, ВУКМИР, ВУЛЕН, ВУКСАН, ВУЧЕТА, ВУЛИН, ВУКАЦ, ВУКОСЛАВАЦ, ВУЛИЋ, ВУЈО, ВУЈА, ВУЧО, ВУЧА, ВУЛЕ): Вукашин Сандаљев (П/1582, бр. 40), Вулета Кукара (П/1584, бр. 91), Вучина Дабов, Вукослав (ДАЦ.Дав./1590, бр. 4), Вулија Новачићев (Грег.,пр.зб./1591), Вулин Гаои (П/1596), Вук(о) Новаковић (П/1598), Вуле (та) Дамјанов (П/1598), Вукмир Балић (ДАЦ.Дав./1599), Вулен Андрин (ДАЦ.Грег./15...), поп Вук Давидовић (П.Џ./1600), Вучета Раичков (П/1602, бр. 35), Вукослав Негал (ДАЦ. Грег./1602, бр. 11), Вукославаи Ниегали (П/1611, бр. 39), Вуја Иванов (П/1619, бр. 329), Ђед Вујко, Вулић Ника Вукова (П,пр.зб./1624), гувернадур Вуксан (П.Џ./1627), Вуча Пјеров (П. пр.зб./1632), Вукаи Никаљев (Грег.,пр.зб./1642), Вукаи Ника Дајкова (П. пр.зб./1645.2), Вуле Франков (П.Џ./1678.2).

Импозантан је број различитих имена која у свом саставу садрже вук-, у српском именослову забиљежено је преко 160 различитих имена од ове основе. Тиме основе вук- представља и носи највећи творбени потенцијал у српском именослову (забиљежен је највећи број различитих личних имена од ове основе) (Стојановић 2013: 31-45). И поред тога што словенска имена не представљају значајан корпус у Паштровским исправама, највећи творбени потенцијал носи управо основа вук-, што свједочи о томе да је овај творбени модел био веома укоријењен и у Паштровићима. Култ вука код Срба је имао

${ }^{4}$ Није забиљежено у РЛИ (Грковић 1973: 61) 
посебну вриједност и значај у односе на све остале народе. На овакву употребу могла је утицати велика упућеност на ову животињу, посебно у планинским крајевима, те значај очувања стоке, али, прије свега, што се у митологији „вук” сматра за Србинова претка, а, потом, понајвише, због повезивања „вука” са култом Светог Саве. Познато је колики је значај и поштовање имао Свети Сава код српског народа. Везивање за таквог свеца могло је да значи и жељу да се тиме вук „припитоми”, „умилостиви”, али и да Свети Сава помогне и заштити од свега, па и од вукова, и од опасности и глади (Стојановић 2013). Такво насљеђе присутно је на свим српским прострима, па и у Паштровићима. Без обзира на то што је број личних имена од словенских основа мали у Паштровским исправама, имена од основе вук- су, ипак, фреквентна, и међу најфреквентнијим словенским (са двадесетак различитих имена, именовано је близу 100 лица).

Остала словенска имена су малобројна (Забиљежено је 10 различитих имена: РАДИЋ, РАИЧ, РАДУЛЕ, РАИЧКО, РАДАН, НОВАК, ДАБИЖИВ, КРСТИЋ, БОЖИДАР, ДУША, којима је именовано 21 лице): Радич Иновић, поп Дабижив (П/1529), (ДАЦ. Дав./1567, бр. 1), Новак Андрин (ДАЦ.Дав./1581., бр. 2), Крстић Марков (П/1599, бр. 104), Раич Марковић (П.Див./1603), Новак Андричин (П/1604, бр. 109), Радуле Марков (П. пр.зб./1610), поп Божидар, Крстић Ников (П/1620), Живан Марчић (П. пр.зб./1649.1), Душа Франов Ћурашевић (Грег,,пр.зб./1693), Радан Лучище Вунде (Грег.,пр.зб./163), Раичко Ников (П. пр.зб./1695).

Поставља се питање, зашто у толикој мјери преовладавају хришћанска (црквена) имена над словенским у Паштровћима (судећи према стању у Паштровским исправама). Одговор би се можда могао наћи у великој упућености Паштровића у том периоду на цркву: овај простор, с обзиром на територију, имао је велики број цркава, уз то веома старих. Црквени живот био је веома жив, о чему свједоче и Паштровске исправе, према којима се види да велики број Паштровића тестаментом оставља имање и новчана средстава црквама, свештенству, монасима, за помен на литургијама себи и себи блиских упокојених. То је, заиста, импозантан број.

5. Женска имена нијесу честа. Преовладавају двосложна женска имена на -е у Нј., потом имена на -ица. Остала су ријетка.

5.1. Мали број женских имена условљен је сљедећим: 1) Паштровске исправе односе се, прије свега, на правна и судска акта у којима жене најчешће нијесу учествовале, односно нијесу имале доминантну улогу. 2) Жене се често представљају према мужу, оцу, брату - без именовања (жена Вука Перова, П. пр.зб./1632; за перћију кћери Иванове а жене Лукине, П/1652, бр. 127; сигура добри својијема за себе и своје жене Илија Андров), 3) Жене се именују углавном у случају да је онај у односу на кога се одређују покојник (Стане кћи покојнога Франа Ивова (П/1672), Маре, кћи покојнога Вука Милошева (ДАЦ. Грег./1674), Маре жена покојнога Никиа (П. пр.зб./1682).

5.2. Најчешћа су двосложна женска имена која се у Нј завржавају на -е, што је по поријеклу стари Вј. (из једнакости НА палаталних основа): КАТЕ, CTAHE, MAPE, АНЪЕ, ПАВЕ, JOКЕ. 
Имена на -е су особеност Паштровића (уз још нека подручја говора зетског типа). Нијесмо забиљежили ниједан примјер у којима се ова имена завршавају на -а у Нј. у исправама 16/17. вијека: баба Kame (П/1609, бр. 81), Kame Степиа Марова (П/1632, бр. 239), Стане Вука Перова (П/1646, бр. 117), Анђе Вука Лушина (ДАБ.Суђ./1656, бр. 1-3.а.2), Стане кћи покојнога Франа Ивова (П/1672), Маре, кћи покојнога Вука Милошева (ДАЦ. Грег./1674), Анђе кћи покојнога Вуца Петрова (Грег.,пр.зб./1676), Кате Вукићева (П/1680, бр. 78), Анђе мати Јована Марова, Анђе жена покојнога, Мара Вукова, Паве Лушина (П. пр.зб./1681), Маре жена покојнога Никиа (П. пр.зб./1682).

Сљедећа категорија женских личних имена, с обзиром на феквенцију, јесу она изведена суфиксом -ища (СТАНИЦА, МАРИЦА, МИЛИЦА, РОЗИЦА, ЈЕЛИЦА, КАТИЦА, 6 имена којима је именовано 25 различитих лица): Марица, жена покојнога Ника Иванова (Грег.,пр.зб./1592), Станиияа, кћи покојнога Вулета Дамјанова (П/1594), кћер Марица (ДАЦ.Грег./1597), Станица кћери покојнога Ника Иванчева (Грег.,пр.зб./1601), Милица Стијепова (П.Див./1603), Розица Каикова (П/1604, бр. 72), Станица жена покојнога Рада Алексина (ДАЦ.Дав./1604), Марица жена покојнога Ивана Жинтлице (П/1621, бр. 92).

Остала лична женска имена забиљежена су у појединачним примјерима: (НИКОЛАЖА - 1, МАРАЗА - 1, АНЂУША - 5, ЈЕЛА - 1, АНЂЕЛИНА - 1, ЛУЦИЈА - 1, ПАВЕ - 1): жена Николажа, кћи покојнога Вуксана Николина (П/1588, бр. 62), Мараза Томичина (ДАЦ.Грег./1591, бр. 1), Анђуша жена Стијепа Жинтилице а кћи покојнога Стијепа Бојанова, матер моја Катица (П/1609, бр. 81), Анђуша Никова, Анђуша Никошица (П/1609, бр. 97), Анђелина, жена покојнога Бурице Жинтилице (П/1615, бр. 110), Ружа покојнога Ника Иванова (П.Џ./1675).

6. Закључак. Антропонимијски систем Паштровића показује многе специфичности у односу на шири српски простор. Уз лично име обавезно иде патроним на -ов или патроним изражен Гј. (или облик на -[oв]uћ, што може бити и патроним и презиме, бар у неким случајевима). Антропонимијски систем умногоме је показатељ почетног стадијума стварања презимена код Срба (који је прекинут турским освајањима), те може послужити као свједочанство како долази до формирања презимена. Да је процес у превирању, говори то што се у Паштровским исправама 16/17.в. напоредо употребљавају патроними на -ов и -(ов)uћ, односећи се на иста лица: облици на -ов почињу да преовладавају као патроними, потискујући облике на -(ов)uћ, а облици на -(ов)ић добијају значење презимена. У Паштровским исправама знатну превагу имају хришћанска имена (којима је именовано око 600 лица), над словенским (именовано око 170 лица), што је, опет, специфичност овог простора у односу на шири српски простор у истом периоду. Женска имена су ријетка, између осталог и због тога што се жена именује по мужу или оцу (некада и брату), док се жена најчешће именује уколико је муж/отац покојни. Најфреквентнија су мушка двосложна имена на -о (Нико, Радо, Маро, Вуко...): од укупно забиљежених именовања различитих лица (700-800), половина су на -о. Такође су најчешћа и двосложна женска имена која се у $\mathrm{Hj}$ 
завршавају на -e, што је по поријеклу стари Вј. (из једнакости НА): Kame, Стане, Маре, Јоке, Анђе, Паве. Хришћанска (црквена) имена (и она изведена од тих основа) представљају неупоредиву већину у односу на словенска имена (око $550: 150)$.

\section{ЛИТЕРАТУРА}

Грковић 1983: Милица Грковић, Имена у Дечанским хрисовуљама, Нови Сад: Филозофски факултет у Новом Саду, Институт за јужнословенске језике.

Грковћ 1973: Милица Грковић, Речник личних имена код Срба, Београд: Вук Караџић.

Јовановић 2011: Гордана Јовановић, Из српске и пољске средњовековне хришћанске антропонимије, Научни састанак слависта у Вукове дане, 40/1, 221-232.

Јовановић 2005: Миодраг Јовановић, Говор Паштровића, Подгорица: Универзитет Црне Горе.

Маројевић 1984: Радмило Маројевић, Словенски антропоними, Ономатолошки прилози, V, 183-195.

Пешикан 1983: Митар Пешикан, Зетско-хумско-рашка имена на почетку турског доба (други део), Ономатолошки прилози, IV, 121-255.

Стојановић 2013(1): Јелица Стојановић, Лична имена од основе вук- у старим српским поменицима и везивање „вука” за култ Светог Саве код Срба, Међународни научни скуп „Осам векова манастира Милешеве”, Зборник радова, II, Милешева, 2013, 31-45.

Стојановић 2013(2): Јелица Стојановић, Словенска имена у старим српским поменицима (Морачком, Пивском и Поменику Хоче 16-19. вијека), Међународни научни скуп „, Српско језичко наслеђе на мулитикултурном простору Баната”, Темишвар, 218-239.

Стојановић 2013(3): Јелица Стојановић, Словенска и хришћанска имена у Пивском поменику $и$ Поменику Хоче, Научни скуп „Професор доктор Гордана Јовановић”, Митолошки зборник, 29, Рача: Центар за митолошке студије Србије, 163-195.

Чајкановић 1994/4: Веселин Чајкановић, Стара српска религија и митологија. Речник српских народних веровања о биљкама, Сабрана дела из српске религије и митологије, Књига четврта, (прир. Војислав Ђурић), Београд: СКЗ - БИГЗ - Просвета - Партенон.

Шимундић 1988: Mate Šimundić, Rječnik osobnih imena, Zagreb: Nakladni zavod Matice hrvatske. 


\title{
Скраћенице
}

\author{
П - Манастир Прасквица, \\ ДАЦ - Државни архив Цетиње, \\ Дав. - Давидовић (породична збирка), \\ Грег. - Греговић (породична збирка), \\ Грег,,пр.зб. - Греговић (приватна збирка).
}

\author{
Елица Р. Стоянович
}

\section{АНТРОПОНИМИКА И АНТРОПОНИМИЧЕСКИЕ КАТЕГОРИИ В ПАШТРОВСКИХ ДОКУМЕНТАХ (16-19 ВВ.)}

\section{Резюме}

Настоящая работа посвящена антропонимике и присущим ей категориям на материале Паштровских документов, датируемые 16-17 веками. Ради более четкого проявления особенностей антропонимической системы Паштровичей, ркзультаты данного исследования помещены в более широкий контекст сербской антропонимики.

В анализируемом материале рядом с именем регулярно употребляется отчество, заканчивающееся на -ов или имеющее форму Род.п. ед.ч. (в некоторых случаях слова на -[ов]ић могут являтся как отчествами, так и фамилиями). Исходя из этого, можно прийти к выводу, что антропонимическая система Паштровичей того времени является ярким свидетельством начала процесса оформления фамилий: сначала по отношении к одному и тому же человеку употребляются как отчества на ов, так и отчества на -(ов) $и \hbar$, чтобы потом в качестве отчества стала употребляться форма на -ов, а за формой на -(ов)ић закрепилась функция фамилии.

Второй особенностью Паштровских документов является большое число христианских имен (их где-то 600), в то время как имен славянского происхождения намного меньше (их приблизительно 170). Женские имена встречаются редко, а причиной этому, между прочим, являтся тот факт, что в те времена женщины не называли по их именам, а по имени ее мужа или отца (иногда брата). Чаще всего в анализируемом женское имя можно встретить в случае, если у этой женщины мужа/отца уже нет в живых (напр. Анђе, кћи покојнога Мара Перова).

Среди мужских имен самыми частнотными являются двусложные имена на -о (Нико, Paдо, Маро, Вуко...): из общего числа мужских имен ((700-800) половина заканчивается на -о.

Двусложными являются и самые частотные женские имена. Они заканчиваются на -e, а данная форма восходит к старому вокативу: Кате,Стане, Маре, Јоке, Анђе, Паве. Христианских имен, а также имен, мотивированных христианскими именами намного больше, чем имен славянских (приблизительно $550: 150)$.

Ключевые слова: антропонимическая система, антропонимическая категория, имя, отчество, фамилия, суффикс, христианские имена, славянские имена, Паштровские документы. 